\title{
PENERAPAN MARKETING MIX TERHADAP BRAND EQUITY PERGURUAN TINGGI SEBAGAI SEBUAH TINJAUAN LITERATUR
}

\author{
Dra. Roslinda Sagala, M.Si
}

\begin{abstract}
ABSTRAK
The process of marketing mix (marketing mix) are successful have a positive impact on brand equity (brand equity). Every marketer trying to take advantage of the marketing mix strategy as a competitive advantage in increasing the brand equity to brand equity owned by the products or services to attract consumers. Level of awareness of a brand into an important cue for consumers to use and specifies a choice of products. In this case, the products you want to achieve is a knowledge-based products (knowledge base). The product was delivered to the college as the core consumer products that are delivered in the marketing of educational services.

Many empirical studies have been conducted to investigate to what extent the influence of marketing mix on brand equity colleges, both state college Cleaner (PTN) or private (PTS). However, little empirical research which brings together existing research into a comprehensive literature review that elaborates on the influence of marketing mix on brand equity colleges. Thus, the management of higher education as an educational institution can be categorized on the model management services business model, which factors the marketing mix consists of product, price, place, promotion, people, physical evidence, process can be a key factor in enhancing brand equity college.
\end{abstract}

Key words: Marketing Mix, Brand Equity, Real Estate, Higher Education

\section{PENDAHULUAN}

Dewasa ini semakin banyak mahasiswa dari berbagai daerah memutuskan untuk melanjutkan pendidikan ke perguruan tinggi yang disediakan oleh berbagai macam perguruan tinggi negeri maupun swasta. Dengan tingginya tingkat kesadaran masyarakat akan peningkatan skill dan keterampilan baik secara konseptual maupun praktikal, maka perguruan tinggi dianggap mampu untuk memenuhi kebutuhan pasar tenaga kerja dalam menciptakan sumber daya manusia yang berkompeten dibidangnya. Tanggung jawab yang diemban perguruan tinggi tidak hanya terbatas pada proses pengembangan sumber daya manusia semata, tetapi perguruan tinggi juga dituntut untuk mampu menghasilkan SDM terampil yang mampu diserap oleh lapangan kerja secara langsung. Untuk itu perguruan tinggi harus mampu menciptakan iklim dan atmosfir yang kondusif bagi setiap calon mahasiswanya.

Pesatnya perkembangan jumlah perguruan tinggi yang menawarkan program pendidikan membuat banyak perguruan tinggi harus berbenah diri.. Perguruan tinggi merupakan salah satu lembaga pendididikan yang secara formal diserahi tugas dan tanggung jawab mempersiapkan mahasiswa sesuai dengan tujuan pendidikan nasional, yakni mengisi kebutuhan masyarakat akan tersedianya tenaga ahli dan terampil dengan tingkat dan jenis kemampuan yang sangat beragam. Jelas sekali bahwa perguruan tinggi memiliki pengaruh besar terhadap kemajuan ekonomi dan pendidikan suatu bangsa, dimana penekanan kualitas dalam proses pendidikan 
menjadi sebuah aktifitas yang akan berpengaruh langsung terhadap kemampuan lulusan, sehingga juga akan bepengaruh terhadap penyerapan tenaga kerja dan peningkatan Brand equity perguruan tinggi tersebut.

Keterlibatan Perguruan tinggi sebagai institusi ilmiah mencerminkan unsur-unsur dan kelembagaan serta berbagai fungsinya untuk menghasilkan keluaran yang berkualitas. Menurut Indrajit dan Djokopranoto, $(2004$, h. 13) perguruan tinggi di Indonesia dapat diklasifikasikan sebagai: Akademi, Institut, Politeknik, Sekolah Tinggi dan Universitas. Dengan adanya pengklasifikasian bentuk perguruan tinggi di Indonesia, maka aspek dalam proses pemasaran harus bekerja dengan sempurna. Pemilihan segmen pasar perguruan tinggi, positioning, dan penempatan produk dibenak pelanggan harus tepat, karena selanjutnya brand dari sebuah perguruan tinggi akan menjadi semacam sebuah kontrak kepercayaan (a contract of trust) antara penyedia jasa (perguruan tinggi) dan pelanggan (mahasiswa) karena ia menjamin adanya konsistensi bahwa sebuah produk akan selalu dapat menyampaikan nilai yang diharapkan konsumen darinya. Oleh karena itu, kemampuan perguruan tinggi dalam meningkatkan brand equity menjadi faktor krusial. Mahasiswa yang puas akan loyal pada perguruan tinggi, selanjutnya mahasiswa tersebut akan merekomendasikan para calon mahasiswa lainnya terhadap suatu nama perguruan tinggi tertentu sehingga pelanggan (mahasiswa) dapat membantu dalam meningkatkan brand equity dari sebuah perguruan tinggi (Dewi, 2005; Andre, 2006).

Brand equity menjadi penting sebagai efek differensial positif yang ditimbulkan pengetahuan nama merek terhadap pelanggan atas produk atau jasa tersebut (Kotler dan Keller, 2006). Salah satu cara untuk meningkatkan brand equity adalah dengan meningkatkan reputasi dari perguruan tinggi. Reputasi perguruan tinggi diraih melalui proses yang panjang dan kompleks (Dewanti dkk, 2007). Kualitas lulusan, fasilitas, proses belajar-mengajar, dan faktor lainnya yang tercakup dalam bidang pendidikan, penelitian, dan pengabdian masyarakat turut menentukan reputasi atau nama baik perguruan tinggi. Dengan begitu, daya saing utama yang menjadi prioritas dari perguruan tinggi sebagai penyedia jasa adalah produk yang berbasiskan pengetahuan atau yang lebih dikenal dengan istilah knowledge base (Yasri, 2006).

Semakin berkembangnya perubahan zaman, orientasi sistem pendidikan, dan permintaan akan tenaga kerja terdidik, maka akan tercipta sebuah perubahan yang sangat besar pada setiap organisasi pendidikan. Globalisasi yang terjadi telah memaksa setiap individu dan organisasi dimanapun untuk melakukan transformasi diri. Maka itu, model pengelolaan perguruan tinggi dapat disetarakan dengan model bisnis jasa. Model bisnis ini termasuk kedalam proses pemasaran, dimana Dharmmesta, $(1997, \mathrm{~h} .3)$ mendefinsikan pemasaran sebagai: "kegiatan-kegiatan pokok yang dilakukan oleh perusahaan untuk mempertahankan kelangsungan hidupnya, dan mendapatkan laba" Dharmmesta, (1997, h. 3). Lebih lanjut Kotler dan Keller, (2009) mendefinisikan definisi pemasaran terkini sebagai" "proses kemasyarakatan yang dilakukan individu dan kelompok untuk memperoleh apa yang mereka butuhkan dan inginkan melalui penciptaan, penawaran dan 
pertukaran secara bebas produk dan jasa nilai dengan pihak lain" Kotler dan Keller, (2009, h. 45).

Dengan dimasukannya pengelolaan perguruan tinggi ke dalam model pegelolaan bisnis jasa, maka perguruan tinggi tidak hanya melakukan pemasaran eksternal, tetapi juga pemasaran internal dan pemasaran interaktif dengan melibatkan mahasiswa dan sumber daya manusia yang dimiliki (Kotler, 1997). Pemasaran interaktif yang dimaksud adalah dengan lingkungan individu mahasiswa yang terdiri dari budaya, kelas sosial, kelompok referensi dan keluarga. Selanjutnya kepuasan stakehoder (mahasiswa, dosen, staff dan pengelola) juga menjadi ukuran keberhasilan perguruan tinggi dalam mengelola manajemennya serta tetap mengutamakan mutu akademik sebagai produk jasa yang harus dicapai (Sembiring, 2009). Dengan begitu, banyak perguruan tinggi terus berusaha untuk mengevaluasi pelayanannya dengan menggunakan metode kualitatif maupun metode kuantitaif sebagai upaya untuk mendapatkan respon dari mahasiswanya (Pratminingsih, 2006).

Telah banyak penelitian yang dilakukan untuk melihat faktor apa saja yang dapat meningkatkan brand equity dari sebuah perguruan tinggi. Kualitas layanan jasa, marketing mix, kepuasan pelanggan eksternal, citra merek (brand image), asosiasi merek (brand assosiation), fasilitas teknologi informasi, program studi, aktifitas mahasiwa, citra layanan dan manajemen merupakan variabel yang selalu diperhatikan oleh calon pengguna jasa dalam menetapkan perguruan tinggi mana yang akan mereka pilih (Sembiring, 2009; Wardi, 2007; Dewanti dkk, 2007; Andre, 2009; Hidayati, 2008; Widajati, 2009; Suryana, 2007). Sebagai contoh, penelitian yang dilakukan Hidayati, (2008) mengemukakan bahwa layanan pendidikan dan citra layanan menjadi faktor yang paling krusial pada perguruan tinggi swasta. Selanjutnya Sembiring, (2009) meneliti pengaruh marketing mix terhadap brand equity Perguruan Tinggi Swasta (PTS) yang menghasilkan kesimpulan bahwa marketing mix yang memiliki tujuh dimensi, memperlihatkan dimensi place, dan dimensi kualitas layanan jasa sebagai faktor penentu bagi calon mahasiswa dalam menetapkan pilihan perguruan tinggi.

Semakin meratanya jumlah penelitian-penelitian yang telah dilakukan untuk mengukur brand equity dengan objek perguruan tinggi menjadi referensi yang baik bagi perkembangan ilmu pengetahuan dan bagi perguruan tinggi itu sendiri. Faktor-faktor yang dapat meningkatkan kesadaran pelanggan seperti hubungan yang dekat dengan pelanggan (close relationship) akan berpengaruh terhadap kepuasan dan loyalitas terhadap institusi pendidikan (Thurau, 2001, h. 340). Tetapi, dengan jumlah penelitian yang begitu melimpah, perlu dilakukan sebuah tinjauan literatur mengenai sejauh apa efektifitas aplikasi tujuh dimensi marketing mix yang terdiri dari Product, price, place, promotion, people, physical evidence dan process terhadap brand equity dari perguruan tinggi. Alasan dilakukannya penulisan karya tulis ini terdiri dari 4 tujuan yaitu, 1.Untuk menghimpun hasil studi empiris yang telah ada dan merangkumnya ke dalam sebuah tinjauan literatur. 2.Untuk mengelaborasi pentingnya bauran pemasaran jasa (Marketing mix) terhadap brand equity perguruan tinggi. 3.Untuk menyajikan sebuah model konseptual yang terintegrasi dari hasil penulisan karya ilmiah ini. 
4.Mendapatkan rekomendasi mengenai praktik dan penerapan marketing mix berdasarkan penelitian-penelitian yang telah tersedia.

Dengan demikian untuk memperluas kajian terdahulu, maka karya tulis ini secara komprehensif akan mengulas penerapan (aplikasi) marketing mix terhadap brand equity perguruan tinggi. Data dan hasil penelitian yang dihimpun penulis didapat berdasarkan penelitian-penelitian empiris yang telah ada baik dari jurnal dalam negeri, luar negeri, buku, serta literatur-literatur penunjang. Setelah menyajikan definisi dari marketing mix dan brand equity, akan dihadirkan sebuah model terintegrasi dari aplikasi marketing mix terhadap brand equity. Permasalahan utama yang akan diangkat dalam model ini didasarkan pada pembagian perguruan tinggi yang diklasifikasikan sebagai Perguruan Tinggi Negeri (PTN) dan Perguruan Tinggi Swasta (PTS).

\section{PERGURUAN TINGGI DI INDONESIA}

Pendidikan tinggi di Indonesia mengalami perubahan panorama selama dekade terakhir ini. Perubahan panorama yang dimaksud meliputi perubahan paradigma, perubahan pengelolaan, perubahan persaingan, dan sebagainya. Perubahan paradigma terutama dipicu oleh perkembangan teknologi informasi sehingga e-learning, euniversity dan sejenisnya mulai banyak dibicarakan dan diusahakan. Perubahan pengelolaan menyangkut badan penyelenggara pendidikan tinggi, baik yang diselenggarakan pemerintah maupun swasta (Indarajit dan Djokopranoto, 2004).

Indrajit dan Djokopranoto, (2004) dalam bukunya "Manajemen Perguruan Tinggi Modern" berpendapat bahwa Perguruan tinggi tidak hanya perlu dilihat sebagai pusat ilmu pengetahuan, pusat penelitian, dan pusat pengabdian masyarakat, tetapi juga suatu entitas korporat 'penghasil ilmu pengetahuan' yang perlu 'bersaing' untuk menjamin kelangsungan hidup. Persaingan, sebagai mana dialami oleh perusahaan for profit, meliputi persaingan dibidang mutu, harga, dan layanan. Situasi persaingan yang ketat ini menyebabkan banyak perguruan tinggi mengalami banyak kesulitan untuk meningkatkan jumlah mahasiswanya. Sementara itu calon mahasiswa memiliki kemudahan dalam memilih nama perguruan tinggi yang dapat memenuhi keinginannya (Andre, 2009). Perguruan tinggi sebagai suatu entitas non profit, juga menghadapi hal yang sama. Untuk pengelolaan semua itu, maka diperlukan pengetahuan dan ketrampilan manajemen, yaitu manajemen perguruan tinggi.

Peraturan Pemerintah Nomor 60 Tahun 1999 tentang Pendidikan Tinggi mengatur bahwa penyelenggara perguruan tinggi yang dilakukan oleh masyarakat haruslah berbentuk yayasan atau badan yang bersifat sosial. ketentuan ini dimaksudkan untuk memberikan status badan hukum pada penyelenggara pendidikan tinggi. Jadi ada semacam penjenjangan dalam penyelenggaraan perguruan tinggi swasta yaitu, jenjang pertama Universitas dan jenjang ke dua Yayasan. Untuk perguruan tinggi negeri, perguruan tinggi itu sendiri sudah merupakan Badan Hukum Milik Negara (BHMN) yang bersifat nirlaba, sejajar dengan Badan Usaha Milik Negara (BUMN).

Dalam perkembangannya, perguruan tinggi milik swasta juga memiliki semacam badan hukum tersendiri. Motivasi ini didorong oleh penilaian bahwa dengan adanya 
dua jenjang penyelenggaraan perguruan tinggi swasta, terdapat birokrasi yang tinggi sehingga menghambat kelincahan gerak perguruan tinggi swasta. Dengan dijadikannya perguruan tinggi swasta menjadi badan hukum sendiri, maka perguruan tingi swasta dapat bertindak lebih mandiri, otonom, dan tidak memerlukan lagi badan hukum lain sebagai cantolannya (Indrajit dan Djokopranoto, 2004).

\section{BAURAN PEMASARAN (MARKETING MIX)}

Marketing mix merupakan salah satu strategi pemasaran yang paling banyak digunakan oleh pemasar (marketer). Strategi ini tidak hanya diaplikasikan pada bisnis produk dan jasa semata, tetapi dapat diterapkan pada model pengelolaan perguruan tinggi yang dimasukan ke dalam model bisnis jasa (Andre, 2009; Sembiring, 2009). Selain itu, kualitas dalam jasa adalah faktor terpenting sebagai kondisi dinamis yang berhubungan dengan produk, jasa, manusia, proses dan lingkungan yang memenuhi atau melebihi harapan (Tciptono 2000 dalam Sembiring, 2009). Lebih lanjut, marketing mix memiliki pengaruh positif dan signifikan terhadap kualitas jasa (Sembiring, 2009). Mc Carthy dalam Dharmmesta, (1997) membagi kombinasi aspek-aspek strategi pemasaran atau yang lebih dikenal dengan sebutan $4 \mathrm{P}$ dari marketing mix. Aspek-aspek $4 \mathrm{P}$ dapat dilihat pada Tabel 1.1.

Tabel 1.1. Perincian 4 P dari Marketing Mix.

Tabel 1.1. Perincian 4 P dari Marketing Mix.

\begin{tabular}{|c|c|c|c|}
\hline $\begin{array}{l}\text { Product } \\
\text { (produk) }\end{array}$ & $\begin{array}{l}\text { Place (sistem } \\
\text { Distribusi) }\end{array}$ & $\begin{array}{l}\text { Promotion } \\
\text { (kegiatan distribusi) }\end{array}$ & Price (harga) \\
\hline Kualitas & $>$ Saluran distibusi & $>$ periklanan & $>$ Tingkat harga \\
\hline $\begin{array}{l}\text { Features dan } \\
\text { style }\end{array}$ & $\begin{array}{l}\text { Jangkauan } \\
\text { distribusi }\end{array}$ & $\begin{array}{l}>\text { Personal selling } \\
>\text { Promosi }\end{array}$ & $\begin{array}{l}>\text { Potongan harga } \\
>\text { Waktu }\end{array}$ \\
\hline$>$ Merek dan & $>$ Lokasi penjualan & penjualan & pembayaran \\
\hline $\begin{aligned} & \text { kemasan } \\
> & \text { Product line }\end{aligned}$ & $\begin{array}{l}>\text { Pengangkutan } \\
>\text { Persediaan }\end{array}$ & $>$ Publisitas & $\begin{array}{l}>\text { Syarat } \\
\text { pembayaran }\end{array}$ \\
\hline $\begin{array}{l}\text { Tingkat dan } \\
\text { pelayanan }\end{array}$ & $>$ penggudangan & & $>$ Cadangan \\
\hline
\end{tabular}

(1997, h. 125).

Dari tabel 1.1 di atas dapat disimpulkan bahwa marketing mix (4 P) terdiri dari product, place, promotion, dan price. Santon dalam Dharmmesta, (1997, h. 124) mendefinisikan marketing mix sebagai: "kombinasi dari empat variabel atau kegiatan inti dari sistem pemasaran perusahaan yang terdiri dari 4 P dan tiap bagian dari marketing mix tersebut merupakan variabel-variabel terkendali (controllabel) yang dapat digunakan perusahaan untuk mempengaruhi tanggapan konsumen dari segmen pasar tertentu yang dituju perusahaan" (Dharmmesta, 1997, h. 124).

Aspek-aspek $4 \mathrm{P}$ sangat menunjang keberhasilan sebuah perusahaan dalam mencapai tujuan yang ditargetkan. Selain untuk mendukung aktifitas manajemen, maka diperlukan tambahan variabel yang khusus menangani model bisnis jasa. Menururt Lovelock dan Wright, (2005) ada model 8P manajemen jasa terpadu yang menyoroti delapan variabel keputusan bagi manajer perusahaan jasa yaitu, Product, Place and Time, 
Process, Productivity and Quality, People, Promotion and Education, Phisycal Evidence, Price. Selanjutnya, Ada yang menarik dari hasil penelitian yang dilakukan Ambarkahi (2007) yang secara tidak langsung melemahkan marketing mix sebagai faktor penunjang dalam meingkatkan brand Equity atupun keputusan calon mahasiswa dalam memilih perguruan tinggi. Penelitian Ambarkahi, (2007) menyimpulkan bahwa tidak semua faktor bauran pemasaran mempunyai pengaruh yang signifikan terhadap keputusan mahasiswa memilih kuliah di perguruan tinggi swasta (PTS). Faktor yang tidak berpengaruh secara signifikan tersebut adalah faktor product dan people. Hasil penelitian Ambarkahi, (2007) tentu saja memberikan informasi pada kita bahwa tidak seluruh variabel bauran pemasaran jasa memiliki pengaruh secara signifikan terhadap keputusan calon mahasiswa untuk memilih perguruan tinggi.

Selanjutnya Sofyandi, Hendri, dan Budi; Kalsum (2008) melakukan penelitian tentang penerapan marketing mix yang terdiri dari $7 \mathrm{P}$, product, price, place, promotion, people, physical evidence, dan process pada persepsi mahasiswa terhadap Perguruan tingggi di Bandung dan Medan. Berdasarkan penelitian yang mereka lakukan, ternyata strategi marketing mix secara simultan berpengaruh signifikan terhadap keputusan mahasiswa dalam memilih perguruan tinggi (Sofyandi, Hendri, Budi, 2008; Kalsum, 2008). Penelitian yang dilakukan Sofyandi dkk, (2008) dan Kalsum (2008) mematahkan hasil penelitian yang dilakukan oleh Ambarkasih (2007).

Untuk mengelaborasi strategi marketing mix, maka Lovelock dan Wright, (2005) membaginya ke dalam 8 kategori yaitu:

1. Product (Elemen Produk). Banyak orang berfikir bahwa produk merupakan barang yang ditawarkan berupa barang yang terlihat secara kasat mata. Tetapi produk secara luas menawarkan kepuasan atas keinginan dan kebutuhan termasuk barang secara fisik, jasa, pengalaman, peristiwa, orang, tempat, organisasi, informasi, ataupun ide (Kotler dan Keller 2009). Selain itu, produk memuat semua komponen kinerja jasa yang menciptakan nilai bagi pelanggan (Lovelock dan Wright, 2005). Bagi pemakai jasa perguruan tinggi, produk dapat disimpulkan sebagai elemen terpenting dari sebuah jasa pendidikan, dengan upaya untuk memuaskan konsumen atas keinginan dan kebutuhannya yang bersifat tidak berwujud (intangible) dan hanya dapat dikonsumsi pada waktu yang bersamaan dengan partisipasi konsumen yang prosesnya tidak dapat disimpan (Kalsum, 2008). Dalam hal ini, jasa diarahkan pada tindakan intangible atau diarahkan pada mental manusia, yaitu pendidikan.

2. Place (Tempat). Tempat merupakan keputusan manajemen mengenai kapan, dimana, dan bagaimana menyampaikan jasa kepada pelanggan. Pentingnya tempat atau lokasi tergantung pada jenis dan tingkat interaksi yang terlibat (Kalsum, 2008). Kotler dan Keller (2009) dalam bukunya yang berjudul "Marketing Management" menyatakan bahwa place (distribusi) mencakup aktivitas perusahaan untuk menyediakan produk bagi konsumen sasaran. Untuk penyediaan jasa pendidikan, maka interaksi penyedia jasa dengan pelanggan terdiri dari 2 interaksi yaitu, pelanggan mendatangi penyedia jasa, penyedia jasa mendatangi pelanggan atau pelanggan dan penyedia jasa mentransaksikan bisnis dalam jarak jauh. 
3. Process (Proses). Proses adalah metode pengoperasian atau serangkaian tindakan tertentu, yang umumnya berupa langkah-langkah yang diperlukan dalam suatu urutan yang telah ditetapkan Lovelock dan Wright, (2005). Lingkungan fisik termasuk ke dalam bagian proses dari penyediaan jasa pendidikan. Lingkungan fisik menjadi faktor pendukung penentu keputusan calon mahasiswa dalam memilih perguruan tinggi yang akan dimasukinya. Diantaranya adalah proses yang dimulai dengan kunjungan untuk melihat bangunan, ruang kuliah, perpustakaan, laboratorium komputer dan manusia, dimana penyedia jasa dan konsumennya berinteraksi dan setiap komponen tangible memfasilitasi penampilan atau kounikasi jasa tersebut (Kalsum, 2008).

4. Productivity and Quality (Produktivitas dan Kualitas). Produktivitas adalah seberapa efisien pengubahan input jasa menjadi output yang menambah nilai bagi pelanggan. Sedangkan kualitas adalah sejauh mana suatu jasa memuaskan pelanggan dengan memenuhi kebutuhan, keinginan dan harapan mereka (Lovelock dan Wright, 2005). Hidayati, (2008) dalam penelitiannya menyatakan bahwa analisis kualitas jasa pendidikan dapat membentuk citra layanan pada perguruan tinggi. Fokus dari kualitas adalah pada kepuasan pelanggan dimana kebutuhan, keinginan,dan harapan pemakai jasa dapat terpenuhi melalui jasa yang dikonsumsi dimana citra layanan tersebut dapat terbentuk dari faktor tanggung jawab dan mutu lulusan.

5. People (Orang). Menururt Payne, (2003) people bagi pemasaran jasa menjadi sangat penting, keberhasilan memasarkan suatu jasa berkaitan erat dengan selection, training, motivation, dan management people. Orang adalah karyawan (dan kadang-kadang pelanggan lain) yang terlibat dalam proses produksi (Lovelock dan Wright, (2005). Selanjutnya Kalsum, (2008) menyatakan bahwa yang termasuk kedalam people terdiri dari staff pengajar, staff administrasi, pustakawan dan teknisi, yang dimiliki oleh lembaga pendidikan tersebut yang memainkan peranannya selama proses komunikasi jasa berlangsung. Staff yang penuh perhatian, cekatan dan ramah dapat memberikan kepuasan kepada konsumen, oleh karena itu personil dan orang-orang yang profesional dalam bidangnya juga akan mempengaruhi keputusan calon mahasiswa dalam memilih perguruan tinggi (Ambarkahi, 2007).

6. Promotion and Education (Promosi dan Edukasi). Lovelock dan Wright, (2005) mendefinisikan Promosi dan edukasi sebagai semua aktivitas dan alat yang menggugah komunikasi dan dirancang untuk membangun preferensi pelanggan terhadap jasa dan penyedia jasa tertentu. Promosi yang menyangkut ketersediaan informasi mengenai administrasi dan registrasi perkuliahan turut menjadi faktor penentu dalam aktivitas promosi (Ridwansyah dan Maulana, 2008). Selain itu Dewanti dkk, (2007) melakukan penelitian bahwa brand awareness harus selalu ditingkatkan dengan melakukan brand recall, maka itu diperlukan pengelolaan promosi yang akan membantu perusahaan dalam menstimuli pembelian atas barang maupun jasa (Dewanti, Masruroh, Doni, 2007; Kotler dan Keller, 2009).

7. Phisycal Evidence (bukti fisik). Bukti fisik adalah petunjuk visual atau berwujud lainnya yang memberikan bukti atas kualitas jasa. Bukti fisik dapat berupa fasilitas 
seperti gedung, kelas, laboratorium yang dimiliki Universitas, penampilan pegawai, dosen, staff dan manajemen Universitas yang secara langsung dapat dilihat oleh calon mahasiswa. Lingkungan fisik ini dapat mempengaruhi persepsi konsumen dan kualitas pelayananan jasa (Sofyandi, Hendri, Budi, 2008; Ambarkahi, 2007; Payne, 2003).

8. Price (Harga dan Biaya Jasa Lainnya). Harga merupakan pengeluaran uang, waktu dan usaha oleh pelanggan untuk membeli dan mengkonsumsi jasa (Lovelock dan Wright, 2005). Tetapi harga dapat hadir dengan berbagai bentuk dan berbagai macam fungsi seperti, sewa, biaya kuliah, ongkos, tarif, bea, biaya gaji dan komisi menjadi harga yang kita bayar sebagai usaha untuk mendapatkan barang maupun jasa yang kita butuhkan (Kotler dan Keller, 2009), sehingga konsumen akan bersedia membayar lebih untuk suatu merek di atas produk-produk sejenis karena merek tersebut dipersepsikan mempunyai nilai lebih (value added) dibandingkan dengan komoditas generik (Dewi, 2005).

\section{BRAND DAN BRAND EQUITY}

Menururt American Marketing Association dalam Suryana, (2007) merek (brand) adalah: "Nama, istilah, tanda, simbol, rancangan atau kombinasi, dari hal-hal tersebut yang ditujukan untuk mengidentifikasi dan membedakan barang atau layanan seorang penjual lainnya" (Suryana, 2007, h. 77). Selain itu, Merek tidak hanya sekedar sebuah nama dan bukan juga sekedar logo atau simbol, tetapi merek adalah payung yang merepresentasikan produk atau layanan (Kartajasa, 2001). Tanpa sebuah merek, sebuah produk hanya akan menjadi komoditas (Dewi, 2005). Merek juga mengandung beberapa unsur, seperti atribut, manfaat, nilai (value), budaya, kepribadian, dan pemakai (Rangkuti, 2004). Merek menjadi penting bagi konsumen, karena merek merupakan jaminan dan konsistensi mutu layanan tersebut (Simamora, 2003). Lebih lanjut, konsumen yang loyal pada merek akan membentuk suatu basis yang solid bagi profitabilitas merek itu (Dharmmesta, (1999).

Brand memainkan fungsi yang bernilai bagi perusahaan karena menawarkan perlindungan yang sah untuk fitur-fitur atau aspek unik yang dimiliki oleh sebuah produk (Kotler \& Keller, 2009). Hal ini dapat menjadi kontribusi tambahan yang membedakan satu produk dengan produk lainnya dalam membandingkan harga maupun jenis produk yang sama secara identik. Dengan begitu, satu brand sulit sulit ditiru karena persepsi yang konsisten dari kosumen atas nilai, karenanya brand dapat menjadi sumber daya saing yang bisa berlangsung lama (Srinivasan dkk, 2005; Dewi, 2005). Selain itu, dengan berinvestasi pada produk atau jasa, maka marketer akan mendapat keuntungan berupa peningkatan brand equity dalam jangka waktu panjang yang nantinya bisa berimbas pada keputusan pembelian yang dilakukan konsumen (Walgren, Ruble, Donthu, 1995; Dewi, 2005).

Menurut Kotler \& Keller, (2009), Brand equity dapat dikelompokan menjadi Brand awareness, brand image, Brand Association, brand responses dan brand relationships. Selain itu, Aaker dalam (Durianto, 2004) juga mengelompokan Brand Equity kedalam lima kategori yaitu, Brand awareness, atau kesadaran merek yang menunjukan kesanggupan 
seorang pembeli untuk mengenali atau mengingat kembali bahwa suatu merek merupakan bagian dari kategori produk tertentu. Kedua Brand Association atau asosiasi merek, mencerminkan pencitraan suatu merek terhadap suatu kesan tertentu dalam kaitannya dengan kebiasaan, gaya hidup, manfaat, atribut produk, geografis, harga, pesaing, selebritis, dan lain-lain. Ketiga Percived Quality atau persepsi kualitas, mencerminkan persepsi pelanggan terhadap keseluruhan kualitas atau keunggulan suatu produk maupun jasa layanan berkenaan dengan maksud yang diharapkan. Keempat Brand Loyalty, mencerminkan tingkat keterikatan konsumen dengan satu merek produk. Kelima aset merek lainnya (Other proprietary brand asset), seperti hak paten, rahasia teknologi, rahasia bisnis, akses khusus terhadap pemasok ataupun pasar lain. Jika keseluruhan aktivitas pemasaran harus diringkas menjadi satu saja, maka kata yang keluar adalah branding. Jika semua tujuan pemasaran digabung menjadi satu, maka yang menjadi tujuan pemasaran adalah brand loyalty (Dewi, 2005).

Erdem dan Swait, (1998) meneliti bahwa konsumen akan mencari informasi pasar atas sebuah produk atau jasa sebagai isyarat dan preferensinya dalam menentukan pilihan. Lebih lanjut, Osselaer dan Alba, (2000) melakukan penelitian dengan melaksanakan empat eksperimen terhadap proses belajar konsumen (consumner learning) dan ekuitas merek (brand equity). Dari hasil penelitiannya Osselaer dan Alba (2000) menyatakan bahwa nilai dari tempat atau place yang dirasakan konsumen (distribusi produk atau jasa) menjadi sebuah isyarat (signalling) pada proses belajar konsumen terhadap merek tertentu. Dengan begitu, manajemen merek (brand management) sangat diutamakan untuk membangun proses belajar untuk meningkatkan brand equity pada calon konsumen (Erdem dan Swait, 1998; Ossealer dan Alba, 2000).

\section{PROPOSISI MODEL}

Berdasarkan penelitian-penelitian empiris yang telah ada, maka dibuat sebuah proposisi model yang menggambarkan hubungan antara marketing mix dan dimensidimensi brand equity yang terdiri dari brand awareness, brand association, brand loyalty, brand response, brand image dan brand relationship. Dengan meningkatnya Brand Equity pada perguruan tinggi negeri maupun swasta, maka akan meningkatkan kesadaran konsumen atas perguruan tinggi sebagai institusi penyedia jasa pendidikan yang dapat dipilih sebagai upaya peningkatan keterampilan dan skill calon mahasiswa. 


\section{Gambar 1.1. Skema Proposisi Rerangka Aplikasi Marketing Mix pada Brand Equity Perguruan Tinggi Negeri (PTN) dan Swasta (PTS).}

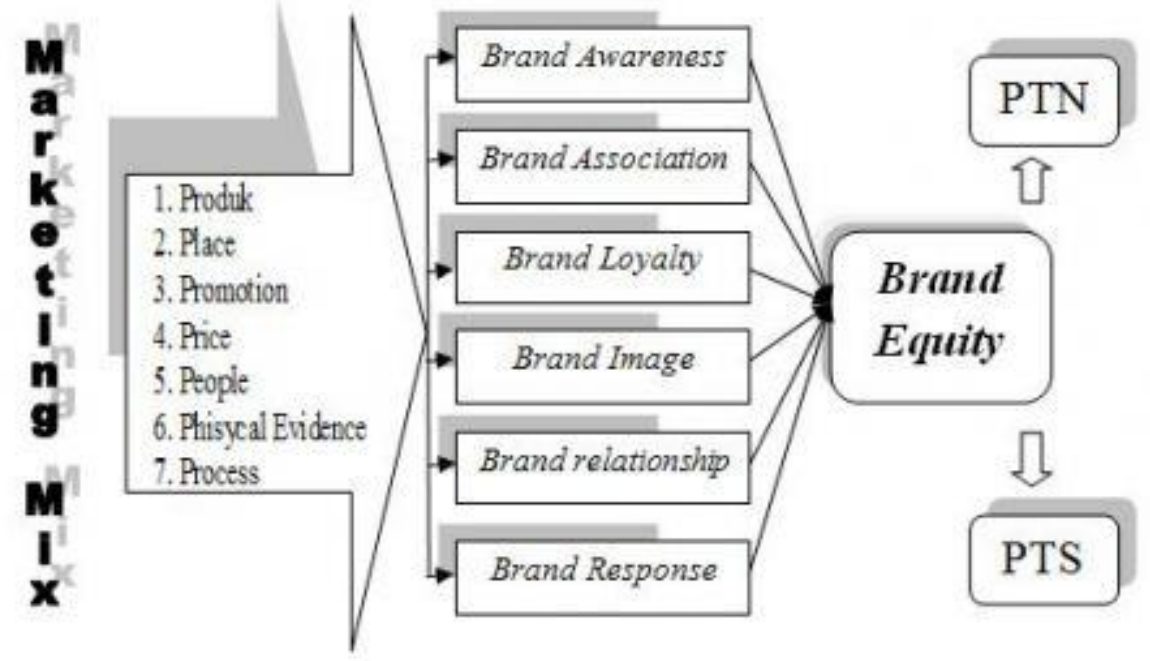

\section{KESIMPULAN DAN IMPLIKASI STRATEGIS}

Dari model di atas dapat disimpulkan bahwa penerapan strategi bauran pemasaran (marketing mix) yang efektif berpengaruh dan dapat meningkatkan brand equity perguruan tinggi negeri (PTN) maupun swasta (PTS) terhadap calon mahasiswanya. Bauran pemasaran jasa yang terdiri dari delapan dimensi, product, price, place, promotion, people, process, physical evidence apabila diaplikasikan secara baik akan berpengaruh langsung pada peningkatan brand awareness, brand association, brand loyalty, brand response, brand image dan brand relationship (Andre, 2009; Sembiring, 2009; Sofyandi, Hendri, Budi, 20008; Kalsum, 2008).

Tingginya brand equity dari merek perguruan tinggi negeri maupun swasta, akan menjadi isyarat (signalling) bagi calon konsumen dalam mencari informasi sebanyakbanyaknya sebagai upaya seleksi terhadap fasilitas dan kualitas yang disediakan oleh perguruan tinggi sebagai penyedia jasa (Erdem dan Swait, 1998; Osselaer dan Alba, 2000). Dengan begitu, dari hasil penelitian empiris yang telah ada dapat kita disimpulkan bahwa aplikasi marketing mix yang efektif memiliki pengaruh untuk meningkatkan brand equity. Selain itu, hal penting yang perlu diperhatikan dalam aplikasi marketing mix adalah mencapai keseimbangan yang efektif, yaitu mengkombinasikan komponen-komponen marketing mix ke dalam suatu strategi pemasaran yang harus disesuaikan dengan situasi dan kondisi perusahaan secara intern (mikro) maupun Ekstern (makro).

\section{DAFTAR PUSTAKA}

Ambarkahi, Y. P. R. (2007), “Faktor Bauran Pemasaran Jasa yang Dipertimbangkan Mahasiswa Dalam Memilih Kuliah di Politeknik Negeri Jember". Jurnal Bisnis dan Manajemen. Vol. 1. Desember, No. 4, h. 339347 
Andre, Y. K. (2009), “Analisis Hubungan Antara Kepuasan Pelanggan dan Loyalitas Pelanggan Terhadap Keinginan Pembelian Ulang, Studi Kasus Universitas Bunda Muliah". Business \& Journal Bunda Mulia, Vol. 5. No. 1 Maret, h. 15-28.

Dewanti, R., Masruroh., \& Doni. B. (2007), "Analisis Brand Equity Bina Nusantara University Dilingkungan SMU Jakarta". Journal The Winners.Vol. 8. No. 2. September, h. 197-213.

Dewi, J. I. (2005), Inspirasi Bisnis: Perspektif Baru Dalam Strategi Branding, Bisnis dan Karir. Yogyakarta: Amara Books.

Dharmmesta, B. S. (1997), Manajemen Pemasaran Analisa Perilaku Konsumen. Edisi 1. Yogyakarta: BPFE.

Dharmmesta, B. S. (1999), Loyalitas Pelanggan: Sebuah kajian Konseptual Sebagai Panduan Bagi Peneliti. Jurnal ekonomi dan Bisnis Indonesia, Vol 14, No. 3, h. 73-88.

Durianto. (2004), Pengukuran Brand Equity Ten. Jakarta: Gramedia Pustaka Utama.

Erdem, T., \& Swait, J. (1998), "Brand Equity As a Signaling Phenomenon". Journal of consumer psychology. Vol. 7. No. 2, pp. 131-157.

Hidayati, M. \& Supratiningrum, (2008), “Analisis kualitas Jasa Pendidikan yang Membentuk Citra Layanan pada Perguruan Tinggi Swasta (PTS) di Semarang". Media Ekonomi dan Manajemen. Vol. 5. No. 1 Januari, h. 117.

Indarajit, E. R \& Djokopratono, R. (2004), Manajemen Perguruan tinggi Modern. Jakarta: STIMIK Perbanas.

Kalsum, U. E. (2008), Analisis Pengaruh Bauran Strategi Pemasaran Terhadap Keputusan Mahasiswa Memilih Fakultas Ekonomi, Universitas Al-Azhar Medan. Tesis. (Tidak dipublikasikan).

Kartajaya, H. (2004), Hermawan Kartjaya on Brand. Bandung: Mizan Media Utama.

Kotler, P. (1997), Manajemen Pemasaran: Analisis Perencanaan, Implementasi dan Kontrol, Terjemahan, Edisi Bahasa Indonesia, Jilid 1 \& 2. Jakarta: Pren Hallindo.

Kotler, P., \& Kevin L. K. (2006), Marketing Management 12th edition. New Jersey: Prentice Hall.

Kotler, P., \& Kevin, L. K. (2009). Marketing Management 13th edition. New Jersey: Prentice Hall.

Lovelock, C. H., \& Wright, L. K. (2005), Manajemen Pemasaran Jasa. Jakarta: PT. Indeks Kelompok Gramedia.

Osselaer V, J. M. S., \& Alba, W. J. (2000), "Consumers Learning and Brand Equity". Journal of Consumers Research. Vol. 27, No. 1. June, pp. 1-16.

Payne, A. (2003), Service Marketing. Prentice Hall, International Ltd. UK.

Pratminingsih, A. S. (2006), "Service Quality in Higher Education: An Approach for Continous Improvement". Jurnal Bisnis, Manajemen, E Ekonomi. Vol. 9. No. 6 November, h. 1123-1133.

Rangkuti, F. (2004), The Powers of Brands: Teknik Mengelola Brand Equity dan Strategi Pengembangan Merek. Jakarta: Gramedia Pustaka Utama.

Ridwansyah, I., \& Maulana, A. (2008), “Pengaruh Bauran Pemasaran Jasa Pendidikan Tinggi Terhadap Loyalitas Mahasiswa Universitas Widyatama". Jurnal Bisnis, Manajemen, E Ekonomi. Vol. 9. No. 6 November, h. 1-17. 
Sembiring, F. K. B. (2009). “Analisis Pengaruh Bauran Pemasaran Terhadap Kualitas Jasa dan Kepuasan Pelanggan Eksternal Perguruan Tinggi Swata di Kota Medan". Jurnal Aplikasi Manajemen Vol. 7, No. 4. November, h. 867-873.

Simamora, B. (2003), Aura Merek. Jakarta: Gramedia Pustaka Utama.

Sofyandi, H., Meriza, H., \& Budi, S. T. (2008), "Persepsi Mahasiswa Angkatan Tahun 2008 Atas Bauran Pemasaran Jasa Universitas Widyatama". Jurnal Bisnis, Manajemen, $\mathcal{E}$ Ekonomi. Vol. 9. No. 6 November, h. 1950-1959.

Srinivasan, V., Park S. C., \& Chang, R. D. (2005), "An Approach to Measurement, Analysis and Prediction of Brand Equity and It Sources". Management Science. Vol. 51. No. 9 September, pp. 1433-1448.

Suryana, P. H. (2007), "Pengaruh Periklanan Terhadap Kesadaran Mahasiswa atas Merek Universitas Pasundan (UNPAS) Bandung". Jurnal Trikonometrika Fakultas Ekonomi UNPAS. Vol. VII. No. 1 Juni, h. 74-85.

Thurau, H. T., Langer, F. M., \& Hansen, U. (2001), "Modelling and Managing Student Loyality: An Approach Based on the Concept of Relationship Quality". Journal of Service Research, Vol. 3. No. 4, May. pp, 331-344.

Undang-Undang Republik Indonesia Tentang Sistem Pendidikan Nasional No 20, Tahun 2003. Jakarata: CV Eko Jaya.

Walgren, C. J. C., Ruble, A. C., \& Donthu, N. (1995), “Brand Equity, Brand Preference, and Purchase Intent". Journal of Advertising. Vol. XXIV. No. 3, pp. 25-40.

Wardi, Y. (2007), “Analisisi Asosiasi Merk dan Pengaruhnya Terhadap Kepuasan Mahasiswa Atas Kualitas Layanan Universitas Negeri Padang". Arthavidya No. 1. h. 2835.

Widajati, D. (2009), "Faktor Brand Image Memotivasi Mahasiswa Untuk Memasuki Jurusan Manajemen Di UPN "Veteran" Jawa Timur". Seminar Nasional Implementasi Sistem Manajemen Kualitas Iso 9001-2008 dan Iwa. Surabaya.

Yasri, M. S. (2006), "Analisis Faktor-Faktor yang Penting Bagi Mahasiswa Perguruan Tinggi Negeri Di Kota Padang Sumatra Barat". Fordema Vol. 6. No. 2. November, h. 139150.

http://bertousman.wordpress.com/2011/10/02/aplikasi-marketing-mix-terhadapbrand-equity-perguruan-tinggi-sebagai-sebuah-tinjauan-literatur/ 